\title{
Menguak Buku Ajaran Radikal di Sekolah
}

\author{
Fathurozi \\ Staf Balai Penelitian dan Pengembangan Agama Semarang
}

\begin{abstract}
Materi yang kurang pantas dikonsumsi anak didik berulang kali muncul di buku agama Islam. Masyarakat Jombang Jawa Timur digegerkan dengan temuan ajaran membunuh orang kafir termuat dalam Buku Pendidikan Agama Islam (PAI) kelas XI SMA. Ajaran radikal ini terlihat pada halaman 78 , yang berbunyi "jika orang menyembah selain Allah atau nonmuslim boleh dibunuh".
\end{abstract}

Pada tahun 2014, buku Sejarah Kebudayaan Islam Kelas VII Madrasah Tsanawiyah terdapat kalimat "Berhala dilakukan oleh agama selain Islam, yaitu Hindu dan Buddha," dan, "Berhala sekarang adalah kuburan para wali". Pada tahun 2013 ditemukan buku PAI dan Budi Pekerti Kelas IV yang diperuntukan bagi siswa Sekolah Dasar juga ada pelajaran hubungan suami-istri dan mimpi basah pada bab soal hadas.

Merujuk Penelitian Umi Masfiah (2012) tentang "Nilai-Nilai Toleransi dan Intoleransi dalam buku PAI di Kota Yogyakarta". Umi menemukan buku PAI Sekolah Dasar yang dicetak oleh lima 5 penerbit, ditemukan buku-buku tersebut takhanya mengajarkan nilainilai toleransi, tetapi mengandung ajaran intoleransi.

Kejadian yang berulang-ulang menimbulkan pertanyaan pada lembaga Pusat Kurikulum dan perbukuan (Puskurbuk), dan Badan standardisasi Nasional Pendidikan (BSNP). Jika terjadi hanya satu kali bisa dikatakan wajar, mungkin mereka capai menyeleksi seluruh buku pelajaran. Padahal lembaga ini bertugas melakukan Standardisasi buku pendidikan. BSNP membagi buku pendidikan menjadi dua kelompok. Pertama buku teks pelajaran. Kedua buku non teks pelajaran.

Merujuk pada PP No. 32 Tahun 2013 tentang Standar Nasional Pendidikan, Pasal 1 ayat 23 berbunyi Buku teks pelajaran adalah sumber pembelajaran utama untuk mencapai Kompetensi Dasar dan Kompetensi Inti.

\section{Peran Guru}

Penyebaran paham radikal tidak semata-mata melalui buku pelajaran agama. Namun guru ikut andil dalam penyembarannya karena guru dalam mengajar hanya mengacu pada teks buku saja. Kelihatannya guru agama hanya menekankan pada materi mengenai surga dan neraka. Mereka beranggapan pelajaran toleransi sudah termuat dalam buku Pendidikan Kewarganegaraan (PKn). Tak ayal sikap siswa kurang mencerminkan nilai-nilai agama dan kurang peduli pada perbedaan keyakinan.

Pelajaran agama mengutamakan teori semata daripada praktek di lapangan dan kurang menyentuh realita kehidupan siswa. Jika siswa berbuat amoral, masyarakat akan memandang guru agama telah gagal. Lebih ironis lagi ketika siswa terlibat gerakan 
radikal. Pada hakekatnya pemahaman keagamaan tak hanya dibebankan pada guru saja, melainkan orang tua siswa, dan masyarakat sekitar.

Pelajaran agama di sekolah terkesan sekadar tambahan karena guru terkadang mengunakan metode ceramah, tanpa adanya interaksi dengan anak didik. Bahkan guru hadir semata-mata sebagai expert yang mahir mengajar, tetapi tidak berperan sebagai "Ayah/lbu" bagi siswa-siswinya.

Di perparah lagipada sekolah-sekolah di bawah yayasan keagamaan, akan selalu menanamankan idiologi organisasi keagamaannya. Tak heran, jika siswa yang belajar di sekolah organisasi keagamaan yang memiliki paham Islam radikal, akan menjadikan siswa kurang toleran, bahkan akan memunculkan bibit-bibit radikal. Namun sebaliknya siswa yang belajar di sekolah organisasi keagamaan yang pola pikir moderat, maka menjadikan siswa lebih pandai menghargai perbedaan agama.

Contoh kasus pelajaran mengenai materi surat al-Kafirun, ada salah satu murid bertanya, Pak guru, tetangga saya ada yang pergi ke gereja? Mereka nanti di akhirat masuk neraka ya? agama Islam harus diyakini sepenuhnya sebagai ajaran benar jawab sang guru. (Masfiah, 2012). Dialog ini mengambarkan guru kurang tegas dalam memberikan jawabannya sehingga menjadikan siswa kebingungan.

Menurut Amin Haedari Direktur Pendidikan Agama Islam, pendidikan agama Islam di sekolah memiliki peran yang strategis dalam membentuk karakter siswa yang beriman, bertakwa dan berakhlak mulia. Guru agama dalam memberikan materi harus memiliki banyak perspektif. Semisal salat diterangkan tak hanya perspektif agama, tetapi mengunakan makna salat dalam perspektif lain, (inilah.com, akses 13/03/2015)

Materi-materi yang terdapat dalam buku agama, tak serta merta diajarkan begitu saja, tetapi harus dipetakkan terlebih dulu. Guru agama harus melepas background idiologi organisasi keagamaan yang diikuti.Maka guru bebas menafsirkan materi agama sesuai kondisi sosial yang terjadi kehidupan bermasyarakat dan bernegara sehingga mencipta kader-kader yang menjunjung tinggi tolerasi antar umat beragama.

Dimuat Koran Bhirawa, 01 Februari 2016

https://www.harianbhirawa.co.id/menguak-buku-ajaran-radikal-di-sekolah/ 